\title{
Aspek Teologis dan Aplikatif Dasa Titah
}

\author{
Rully Runturambi \\ Sekolah Tinggi Teologi Berita Hidup \\ rully.runturambi@gmail.com
}

\begin{abstract}
Believers today are eager to explore the Bible, especially the New Testament, because they believed that the Old Testament is no longer valid in the lives of believers. The discussion in this paper examines the importance of the Decalogue and its application to believers in the present. The Ten Commandments are the culmination (climax) of all the books, centers and themes of the extraordinary book that ever existed. The Ten Commandments are the basis of all Bible themes. The Ten Commandments are the highest foundation of God's law. Many verses in the Bible (Old and New Testaments) are citation extensions of the Ten Commandments. God's command is a measure that enables us to know whether we are on the path that is in accordance with His desires or we are deviating. As John warned in 1 John 3: 4 "Everyone who sins, also violates God's law, because sin is a violation of God's law." From the discussion it is known that the Ten Commandments of God are good news delivered to Israel and also to the Christian nowadays. The Ten Commandments are the good news that God has given us to do. What is meant by the good news is that the Ten Commandments, most of which are in the form of prohibitions or negative things, but behind that all God has good intentions, which are only shown to us believers today.
\end{abstract}

Keywords: Happy, Kingdom of Heaven, poor before God

\begin{abstract}
Abstrak: Orang percaya pada masa kini cukup bersemangat mendalami Alkitab, dan pada umumnya yang dipelajari adalah Perjanjian Baru, karena berpandangan bahwa Perjanjian Lama tidak lagi berlaku dalam kehidupan orang percaya. Pembahasan dalam tulisan ini mengupas pentingnya Dasa Titah dan aplikasinya bagi orang percaya pada masa kini. Sepuluh Perintah merupakan puncak (klimaks) dari seluruh kitab, pusat dan tema kitab yang sangat luar biasa yang pernah ada dan merupakan hasil dari yang kemudian dan tambahan-tambahannya. Sepuluh Perintah adalah merupakan dasar dari seluruh tema Alkitab. Sepuluh Perintah adalah dasar hukum Allah yang tertinggi. Banyak ayat-ayat dalam Alkitab (Perjanjian Lama dan Baru) merupakan perluasan kutipan dari Sepuluh Perintah. Perintah Allah adalah merupakan suatu ukuran yang memampukan kita untuk mengetahui apakah kita berada di jalan yang sesuai dengan keinginan-Nya atau kita sedang menyimpang. Sebagaimana yang diperingatkan oleh Yohanes di dalam 1 Yohanes 3:4" Setiap orang yang berbuat dosa, melanggar juga hukum Allah, sebab dosa ialah pelanggaran hukum Allah." Dari pembahasan diketahui bahwa sepuluh perintah Allah adalah merupakan kabar baik yang disampaikan bagi Israel dan juga bagi orang percaya. Sepuluh Perintah Allah merupakan kabar baik yang Allah telah berikan kepada kita untuk dilaksanakan. Yang dimaksudkan dengan kabar baik adalah bahwa Sepuluh Perintah, yang sebagian besar di dalam setiap perintahnya berupa larangan atau hal yang negatif namun dibalik itu semua Allah mempunyai maksud yang baik, yang hanya ditujukkan bagi kita orang percaya pada masa kini.
\end{abstract}

Kata kunci: berbahagia, kerajaan sorga, miskin di hadapan Allah 


\section{PENDAHULUAN}

Orang percaya pada masa kini cukup bersemangat mendalami Alkitab, dan pada umumnya yang dipelajari adalah Perjanjian Baru, karena Perjanjian baru menjelaskan pekerjaan Yesus Kristus, awal munculnya gereja, dan pengajaran-pengajaran para rasul kepada gereja. Tetapi seringkali orang Kristen masa kini lupa bahwa Alkitab yang ada pada masa Yesus dan gereja awal adalah kitab Perjanjian Lama. Latar belakang untuk pengajaran Yesus dan pengajaran para rasul pada masa itu adalah Perjanjian Lama. Roger Nicole mengatakan: Jelas bahwa penulis Perjanjian Baru, dan Tuhan kita sendiri, sangat dipengaruhi oleh Perjanjian Lama, sehingga mereka memakai kata-kata, cara ungkapan, dan kebenaran-kebenaran dari Perjanjian Lama dalam pengajaran dan penulisan mereka. ${ }^{1}$

Salah satu berita terpenting dari Perjanjian Lama adalah sepuluh perintah Allah yang diberikan oleh Allah sendiri kepada bangsa Israel di Sinai. Bagi orang percaya, pengajaran mengenai "Sepuluh Hukum," "Dasa Titah" atau "Sepuluh Perintah Allah" bukanlah sesuatu yang baru, karena pernah didapat dari kelas katekese, khotbah-khotbah ataupun dari pembahasan Alkitab di gereja. Namun ternyata, banyak orang percaya yang hanya pernah "mendengar" tetapi sesungguhnya belum "mengenal" atau tidak tahu makna sepuluh perintah dan apa relevansinya bagi kehidupan mereka saat ini. Hal ini disebabkan karena saat ini jarang sekali gereja membahas atau mengkotbahkan tentang sepuluh perintah Allah, begitu juga di dalam membahas atau mengkotbahkan tentang Sepuluh Perintah Allah, begitu juga di dalam pertemuan pemahaman Alkitab. Sehingga timbul kesan seakan-akan Sepuluh Perintah tidak relevan lagi dalam kehidupan orang percaya masa kini.

Hampir setiap orang percaya masa kini, yang tumbuh dan dibesarkan dengan pengajaran gereja yang baik, mempunyai pandangan yang negatif terhadap Sepuluh Perintah Allah dan bahkan serta merta menolaknya. Namun sebenarnya, apa yang mereka tolak tersebut hanyalah gambaran yang salah tentang konsep hukum Perjanjian Lama yang diciptakan oleh pemikiran-pemikiran keliru dan kesalahpahaman yang diturunkan generasi demi generasi. Ada orang yang menolak hukum Perjanjian Lama dengan alasan bahwa hukum Perjanjian Lama, termasuk Sepuluh Perintah adalah aturan-aturan orang Yahudi yang tidak relevan lagi untuk orang Kristen. Mereka beranggapan bahwa Kristus telah menggenapinya dengan Hukum Kasih.

Tetapi ketika seorang Kristen ditanya tentang masalah pembunuhan misalnya, mereka akan segera mengacu kembali kepada Sepuluh Perintah Allah. Alasan lain, berawal dari penolakan gereja yang bisa ditelusuri dari sikap dan pemikiran tokoh-tokoh gereja masa post-apostolik (sesudah para rasul) yang penuh dengan semangat permusuhan dan kebencian terhadap bangsa Yahudi. Hukum Taurat dan Sepuluh Perintah selalu dipandang sebagai suatu cara hidup legalistis, yang bersifat lahiriah dan kurang mempunyai nilai-nilai spiritual.

\footnotetext{
${ }^{1}$ Roger Nicole, "The Old Testament in the New Testament," dalam The Expositor's Bible Commentary, ed. Frank E. Gaebelein (Grand Rapids: Zondervan, 1979): 1, 617.
} 


\section{METODE PENELITIAN}

Metode yang dipakai dalam penulisan ini diantaranya adalah metode penelitain induktif melalui studi pustaka teologi Perjanjian Lama dan Perjanjian Baru dan Alkitab. Wellinton Pandensolang, mengatakan bahwa langkah tersebut dipandang relevan dan efektif untuk diterapkan demi menghindari kekeliruan dalam merumuskan suatu kesimpulan yang pada akhirnya menghasilkan pandangan yang menyimpang dari kebenaran yang diharapkan. ${ }^{2}$

\section{Dasar Hukum bagi Israel}

Umberto Cassuto mengatakan bahwa Sepuluh Perintah merupakan hal yang terpenting dari pemberitaan dalam kitab Keluaran dan merupakan tema pokok dari keseluruhan kitab Keluaran. Sepuluh Perintah merupakan puncak (klimaks) dari seluruh kitab, pusat dan tema kitab yang sangat luar biasa yang pernah ada dan merupakan hasil dari yang kemudian dan tambahan-tambahannya. ${ }^{3}$ Sedangkan menurut Herbert Wolf, Sepuluh Perintah adalah merupakan dasar dari seluruh tema Alkitab. Ada dua jenis hukum dalam masa Perjanjian Lama, dan kedua jenis ini umumnya terdapat pada jaman Timur Tengah kuno yaitu :

Pertama, hukum apodiktik, adalah hukum atau perintah yang berisi aturan-aturan yang mengikat. Hukum apodiktik ini bersifat positif maupun negatif. Sepuluh Perintah adalah salah satu contoh dari jenis hukum ini. Kedua, hukum kasuistik, adalah hukum atau perintah yang berdasarkan situasi tertentu. Hukum ini juga bersifat positif dan negatif, sebagai contoh hukum-hukum Musa, seperti contoh Keluaran 21:2-22.

Sepuluh Perintah merupakan pusat perjanjian Musa (Sinai). Kesepuluh Perintah dikenal juga dengan kesepuluh firman (Kel. 34:28; Ul. 4:13; 10:14; diterjemahkan "dekalog" dari bahasa Yunani), perintah-perintah yang singkat dan jelas ini meringkaskan tuntutan-tuntutan hukum dan mewakili hukum moral untuk membedakannya dari hukum sipil atau hukum ritual. Sebagaimana yang telah disebutkan bahwa keSepuluh Perintah hampir sama dengan ketentuan-ketentuan suatu persetujuan, suatu alasan lain bagi umat Israel untuk menaatinya dengan sepenuh hati. "Ditulisi oleh jari Allah" (Kel. 31:18) di atas dua loh batu, keSepuluh Perintah itupun disimpan di dalam tabut perjanjian sebagai suatu tanda pentingnya hukum-hukum tersebut. Kedua loh batu itu mungkin merupakan salinan, yang masing-masing berisi kesepuluh hukum itu. Akan tetapi, sebelum hukum-hukum itu dibacakan kepada bangsa Israel, Musa telah menghancurkan kedua loh batu itu ketika ia melihat bangsa itu sedang menyembah anak lembu emas (Kel. 32:19). Dua loh batu yang baru dipahat dan ditulisi lagi ketika Musa kembali ke puncak gunung itu (Kel. 34:1). ${ }^{4}$ Lebih lanjut Wolf menjelaskan bahwa ada perbedaan pendapat tentang cara yang tepat

\footnotetext{
${ }^{2}$ Wellinton Pandensolang, Argumentasi Teologis Tentang Parousia Berdasarkan 1 Tesalonika 4:13-15 dan Wahyu 19:6-20:15 (Tesis Th.M., Sekolah Tinggi Teologia InjiliIndonesia, 2003), 18.

${ }^{3}$ Umberto Cassuto, A Commentary on the Book of Exodus, translated by Israel Abrahams (Magnes Press: Reprinted English, ed. Jerusalem), 235.

${ }^{4}$ Herbert Wolf, Pentateukh, 206
} 
dalam membagi kesepuluh hukum itu di atas dua loh batu, namun semua setuju bahwa perintah-perintah yang awal berbicara tentang hubungan manusia dengan Allah, dan perintah-perintah yang kemudian menyangkut hubungan manusia dengan manusia sedangkan perintah untuk memelihara sabat bersifat transisi, karena sabat didasarkan atas perhentian Allah dari kegiatan mencipta pada hari ke tujuh dan pada waktu yang sama terjalin erat dengan hubungan antara tuan dengan budak, atau majikan dengan karyawan. Perintah berikutnya: hormatilah ayah dan ibumu (Kel. 20:12) disebut di Efesus 6:2 sebagai "suatu perintah yang penting" dengan sebuah janji ${ }^{5}$

Menurut Jack S. Deere, sebagian besar para sarjana membagi Sepuluh Perintah ke dalam dua bagian besar yaitu; metode Yahudi yang disebut Philonic yang diambil dari nama ahli theologia Yahudi, Philo, membaginya ke dalam dua bagian besar. Orang-orang Yahudi percaya bahwa demikianlah Allah membaginya ke dalam dua loh batu. Orangorang Kristen dan Katolik yang mengikuti Agustinus dengan membaginya ke dalam tiga bagian pertama dan tujuh bagian terakhir. Dasar pembagian ini adalah karena ketiga perintah pertama berkaitan dengan hubungan manusia dengan Allah dan ketujuh terakhir berkaitan hubungan dengan sesama manusia (bandingkan Mat. 22:36-40). Beberapa ahli berpendapat bahwa setiap loh batu berisi Sepuluh Perintah sesuai dengan kebiasaan Timur Tengah di dalam membuat salinan dokumen perjanjian. ${ }^{6}$

Philip C. Johnson menjelaskan bahwa: gereja Protestan Lutheran mengikuti Agustinus dengan menempatkan ayat dua hingga enam sebagai perintah pertama dan membagi ayat tujuh belas menjadi dua bagian. Agama Yahudi (Yudaisme) menempatkan ayat dua sebagai perintah pertama dan ayat ketiga hingga enam sebagai perintah yang kedua. Pembagian yang lebih awal dapat ditelusuri dari Yosefus pada abad pertama Masehi yang menempatkan ayat tiga sebagai perintah pertama dan ayat empat hingga enam sebagai perintah kedua. Pembagian ini didukung oleh semua gereja mula-mula pada gereja mula-mula dan tetap dipegang oleh gereja Ortodoks dan Reformed (Calvin) hingga saat ini. $^{7}$ Di dalam penulisan ini, penulis menggunakan penomoran menurut Ortodoks dan Reformed. Perbedaan pembagian penomoran Sepuluh Perintah antara agama Yahudi, Katolik dan Protestan (Reformed) disajikan dalam tabel sebagai berikut: ${ }^{8}$

${ }^{5}$ Wolf, Pentateukh, 20

${ }^{6}$ Jack S. Deere "Deuteronomy," dalam The Bible Knowledge Commentary: Old Testament, pen. John F. Walvoord and Roy B. Zuck (Wheaton: Scripture Press Publications, Victor Books, 1985), 270.

${ }^{7}$ Philip C. Johnson, "Exodus,"dalam The Wycliffe Bible Commentary, pen., Charles F. Pfeiffer and Everett F. Harrison (Chicago: Moody Press, 1962), 69.

${ }^{8}$ Artikel: www.biblescripture.net/Commandments.html 
Tabel Sepuluh Perintah Allah (Keluaran 20:1-17)

\begin{tabular}{|c|c|c|}
\hline Yudaisme & $\begin{array}{c}\text { Agustinus } \\
\text { Katolik dan Lutheran }\end{array}$ & $\begin{array}{c}\text { Origenes } \\
\text { Ortodoks \& Reformed }\end{array}$ \\
\hline $\begin{array}{l}\text { Akulah TUHAN, Allahmu, } \\
\text { yang membawa engkau } \\
\text { keluar dari tanah Mesir, } \\
\text { dari tempat perbudakan. }\end{array}$ & $\begin{array}{l}\text { Akulah TUHAN, Allahmu, } \\
\text { Jangan ada padamu allah } \\
\text { lain di hadapan-Ku. }\end{array}$ & $\begin{array}{l}\text { Akulah TUHAN, Allahmu, } \\
\text { Jangan ada padamu allah } \\
\text { lain di hadapan-Ku. }\end{array}$ \\
\hline $\begin{array}{l}\text { Akulah TUHAN, Allahmu, } \\
\text { Jangan ada padamu allah } \\
\text { lain di hadapan-Ku. }\end{array}$ & $\begin{array}{l}\text { Jangan menyebut nama } \\
\text { TUHAN, Allahmu, dengan } \\
\text { sembarangan. }\end{array}$ & $\begin{array}{l}\text { Jangan membuat bagimu } \\
\text { patung yang menyerupai apa } \\
\text { pun. }\end{array}$ \\
\hline $\begin{array}{l}\text { Jangan menyebut nama } \\
\text { TUHAN, Allahmu, dengan } \\
\text { sembarangan, }\end{array}$ & $\begin{array}{l}\text { Ingatlah dan kuduskanlah } \\
\text { hari Tuhan. }\end{array}$ & $\begin{array}{l}\text { Jangan menyebut nama } \\
\text { TUHAN, Allahmu, dengan } \\
\text { sembarangan. }\end{array}$ \\
\hline $\begin{array}{l}\text { Ingatlah dan kuduskanlah } \\
\text { hari Sabat: }\end{array}$ & $\begin{array}{l}\text { Hormatilah ayahmu dan } \\
\text { ibumu. }\end{array}$ & $\begin{array}{l}\text { Ingatlah dan kuduskanlah } \\
\text { hari Tuhan. }\end{array}$ \\
\hline $\begin{array}{l}\text { Hormatilah ayahmu dan } \\
\text { ibumu }\end{array}$ & Jangan membunuh. & $\begin{array}{l}\text { Hormatilah ayahmu dan } \\
\text { ibumu. }\end{array}$ \\
\hline Jangan membunuh & Jangan berzinah. & Jangan membunuh. \\
\hline Jangan berzinah & Jangan mencuri & Jangan berzinah \\
\hline Jangan mencuri. & $\begin{array}{l}\text { Jangan mengucapkan saksi } \\
\text { dusta tentang sesamamu. }\end{array}$ & Jangan mencuri. \\
\hline $\begin{array}{l}\text { Jangan mengucapkan saksi } \\
\text { dusta tentang sesamamu. }\end{array}$ & $\begin{array}{l}\text { Jangan mengingini isteri } \\
\text { sesamamu. }\end{array}$ & $\begin{array}{l}\text { Jangan mengucapkan saksi } \\
\text { dusta tentang sesamamu. }\end{array}$ \\
\hline $\begin{array}{l}\text { Jangan mengingini apapun } \\
\text { yang dipunyai sesamamu." }\end{array}$ & $\begin{array}{l}\text { Jangan mengingini apapun } \\
\text { yang dipunyai sesamamu." }\end{array}$ & $\begin{array}{l}\text { Jangan mengingini apapun } \\
\text { yang dipunyai sesamamu." }\end{array}$ \\
\hline
\end{tabular}

Hukum-hukum Allah di dalam kitab Keluaran dibahas mulai dari Keluaran pasal sembilan belas hingga pasal dua puluh empat yang adalah merupakan bagian dari kasih Allah di dalam membangun hubungan pribadi dengan Israel yang nampak dari perlakuan istimewa terhadap Israel dibanding bangsa-bangsa lain. Dari sudut pandang formal, hukum Allah (Kel. 20:1-17; 2-:22-23:33) sesungguhnya adalah bagian dari kisah kasih Allah di dalam membangun perjanjian dengan Israel di Sinai (Kel. 19; 20-18-21; 24). Secara umum, hal tersebut menunjukkan kelanjutan dari kisah Keluaran pasal satu hingga delapan belas dimana Allah dengan kasih-Nya mengambil inisiatif untuk mengadakan hubungan pribadi dengan umatNya, dengan demikian Israel mengetahui Yahweh sebagai Allah mereka (Kel. 6:6-7; 16:12). Adalah penting untuk dicatat bagaimana Allah pertama kali membangun hubungan dengan Israel dengan menyelamatkan mereka dan kemudian 
membangun hubungan melalui penjanjian dan hukum-hukum-Nya. Dengan kata lain, suatu hubungan dengan Allah dibangun tidak hanya melalui ketaatan Israel melakukan hukumhukum-Nya, tetapi dasar yang terutama dan pertama dari hubungan itu sendiri adalah suatu anugerah.

Hubungan Israel dengan Allah telah terjalin sebelum pemberian Sepuluh Perintah atau hukum Allah. Pemberian Sepuluh Perintah itu adalah merupakan suatu babak pembukaan yang menunjukkan bahwa Israel "telah" diselamatkan melalui hubungan pribadi dengan Allah, yang ditunjukkan melalui pernyataan: "Akulah Tuhan..."(Kel. 20:2). ${ }^{9} \quad$ Joe Sprinkle menegaskan juga bahwa hukum Allah tidak pernah dimaksudkan untuk membangun hubungan dengan Tuhan, sebaliknya hukum itu dimaksudkan untuk mengatur hubungan Israel dengan Allah yang sesungguhnya telah terjadi, selain itu Sepuluh Perintah juga dimaksudkan untuk menjadi pedoman bagi mereka yang telah "diselamatkan." Perjanjian Israel dengan Allah tidak terjadi karena mereka baik, karena sesungguhnya, mereka adalah orang yang keras kepala (Ul. 9:6). Perjanjian itu juga tidak dilakukan karena mereka hebat, tetapi semata-mata karena Allah mengasihi mereka (Ul. 7:7-9). Hubungan itu sendiri menyangkut anugerah, bukan hukum. ${ }^{10}$

Edy Peter menjelaskan bahwa perjanjian Israel dengan Allah melalui perjanjian Musa (Mosaic Covenant) adalah suatu perjanjian yang bersifat bersyarat supaya setiap orang yang percaya janji Allah yang diberikan kepada Abraham melalui perjanjian Abraham (Abrahamic Covenant) tahu bagaimana mereka harus melakukan hukum-hukum tersebut. Perjanjian Musa (Mosaic Covenant) secara keseluruhan memiliki tiga aspek yang mengatur kehidupan Israel; Pertama, perintah-perintah yang ditetapkan secara personal, yaitu bagaimana hidup berhubungan dengan Allah secara khusus (Kel 20:1-26); Kedua, penghakiman secara sosial, yaitu bagaimana hidup berhubungan dengan orang lain secara khusus (Kel 21:1-24:11); Ketiga, ordinansi penetapan kehidupan keagamaan mereka supaya umat itu tahu bagaimana menyembah Allah (Kel 24:12-31:18). Perjanjian Musa (Mosaic Covenant) diberikan bukan untuk menggantikan perjanjian Abraham (Abrahamic Covenant), tetapi fungsinya jelas seperti yang dijelaskan oleh Paulus; "Maksudku ialah: janji yang sebelumnya telah disahkan Allah, tidak dapat dibatalkan oleh hukum Taurat, yang baru terbit empat ratus tiga puluh tahun kemudian, sehingga janji itu hilang kekuatannya. Sebab, jikalau apa yang ditentukan Allah berasal dari hukum Taurat, ia tidak berasal dari janji; tetapi justru oleh janjilah Allah telah menganugerahkan kasih karuniaNya kepada Abraham. Kalau demikian, apakah maksudnya hukum Taurat? Ia ditambahkan oleh karena pelanggaran-pelanggaran, sampai datang keturunan yang dimaksud oleh janji itu, dan ia disampaikan dengan perantaraan malaikat-malaikat ke dalam tangan seorang pengantar" (Gal. 3:17-19). ${ }^{11}$

\footnotetext{
${ }^{9}$ Artikel: www.biblescripture.net/Commandments.htm.l

${ }^{10}$ Joe M. Sprinkle, "Law and Narrartive in Exodus 19-24," Journal of the Evangelical Theological Society, Jun 2004: 1.

${ }^{11}$ Edy Peter P, Teologi Perjanjian Versus Dispensasional (Jakarta: STTI Philadelphia, Cet. I), 98-99.
} 
Dari penjelasan Paulus tersebut menunjukkan bahwa hukum Taurat, perjanjian Musa (Mosaic Covenant) yang datang empat ratus tiga puluh tahun setelah perjanjian Abraham (Abrahamic Covenant) ditambahkan berdampingan dengan perjanjian Abraham (Abrahamic Covenant) supaya umat Israel tahu bagaimana harus hidup sampai "benih itu" (the seed) yaitu Kristus, datang dan membuat persembahan yang lengkap dan sempurna yang merupakan antitipe dari tipe korban yang ditekankan dalam perjanjian Musa (Mosaic Covenant). Hukum-hukum Allah, lebih berarti daripada sekedar penyelamatan, tetapi juga berarti sebagai alat untuk membantu Israel menjadi "umat kudus," terpisah bagi Allah (Kel. 19:6) dan hal itu juga berarti adanya tuntutan perilaku yang kudus. Hukum Allah melarang setiap hal yang dapat merusak hubungan Israel dengan Allah (contoh: menyembah allah lain, kerusakan moral ). Hukum Allah mempromosikan hal-hal yang baik di dalam membangun hubungan dengan Allah (festival, sikap dan penyembahan yang benar, perilaku yang baik yang menyenangkan Allah). Dasar kewajiban Israel adalah mengasihi Allah (Ul. 6:4).

Hukum Allah didefinisikan sebagai suatu bentuk perilaku yang harus dilakukan dalam hal mengasihi Allah, dengan demikian kepatuhan kepada hukum adalah merupakan suatu ekspresi iman bagi umat dan setiap pribadi bangsa Israel. Hubungan pribadi dengan Allah menempati setiap saluran kehidupan melalui kesetiaan menanggapi Allah. Hal ini nampak bahwa setiap hukum Taurat terhisab ke dalam setiap aspek kehidupan; moral sosial, dan kehidupan beragama. ${ }^{12}$

J. Vurkuyl mengatakan bahwa, di dalam kitab Perjanjian Lama, hukum Taurat itu biasanya disebut "Torah." Kata Ibrani ini asalnya dari kata kerja "Hora" artinya: mengajar, menunjukkan. Apabila bangsa Israel berhadapan dengan suatu putusan yang penting, maka dimintanya "Torah" dengan perantaraan seorang nabi atau imam: dan "Torah" disitu berarti "petunjuk, petunjuk ilahi, atau keputusan ilahi (bandingkan 1 Sam. 23:9). Yahweh, Allah bangsa Israel, tidak membiarkan umat-Nya berjalan sendiri pada jalan yang ditempuhnya. Ia memperhatikan soal-soal kehidupan umat-Nya itu. Ia memberi pimpinan di dalam masalah-masalah yang dihadapinya, di dalam kesukaran-kesukarannya, di dalam cobaan-cobaan dan godaan-godaan yang dialaminya. Lambat-laun seluruh petunjuk dan keputusan yang diberikan oleh Tuhan itu disebut Torah dan kemudian kata Torah itu dipakai untuk menyebutkan segenap Pentateukh, oleh sebab itu di dalam kitab-kitab itu, petunjuk-petunjuk Allah tadi dikodifikasikan (dihimpun menjadi satu).

Di dalam Alkitab, Torah dipandang sebagai suatu anugerah kasih setia Tuhan. Sebagai tanda bukti bahwa Ia memelihara umat-Nya. Dalam kitab-kitab tafsir yang baru, Torah itu dibagi dengan berbagai cara, sesuai dengan bentuk kesusastraannya. Mengenai isinya, terdapat tiga golongan hukum-hukum dan perintah-perintah.

Pertama, dekalog atau Sepuluh Perintah, yakni kesepuluh perintah Tuhan. Kedua, misypatim, yakni undang-undang hukum sipil yang mengatur kehidupan umat Tuhan sebagai "warganegara" (peraturan-peraturan tentang janda dan yatim piatu,

\footnotetext{
${ }^{12}$ Sprinkle, Law and Narrartive, 2.
} 
orang-orang miskin, budak belian, orang-orang asing, orang-orang sakit). Ketiga, khuqqim, yakni undang-undang yang berisi ketetapan-ketetapan tentang kebaktian. ${ }^{13}$

\section{PEMBAHASAN}

\section{Dasar Teologis Sepuluh Perintah}

Keluaran 20 ayat pertama dan kedua adalah merupakan pembukaan atau perkenalan atas seluruh Sepuluh Perintah, kedua ayat tersebut memiliki hubungan dengan tiga perintah pertama. Alan Cole menjelaskan bahwa ayat pertama memberitakan kepada kita bahwa Allah tidak hanya menuliskan perintah-perintah tersebut pada loh batu, tetapi Dia juga berbicara kepada Israel. Melalui perintah-perintah ini, Allah ingin kita mengetahui bahwa perintah-perintah tersebut bersumber dari Allah. Inspirasi dan penulisannya tentunya tidak dipertanyakan dari generasi ke generasi bangsa Israel yang mendengar pembacaan Sepuluh Perintah ini. ${ }^{14}$

Dalam ayat kedua, Allah Israel dibedakan dengan allah lain yang terlarang. Tindakan Allah di dalam sejarah Israel didasarkan atas hal yang diperintahkan-Nya. Allah pertamatama mengingatkan Israel bahwa Dialah Allah yang berperan dalam sejarah, mengubah sejarah dunia guna memenuhi janji-Nya kepada Abraham dan para bapa leluhur, dan yang membebaskan Israel dari perbudakan di Mesir. Tidak ada allah lain yang mengendalikan sejarah, kedua, Allah bertindak dalam sejarah untuk memberikan berkat dan maksud yang khusus kepada Israel. Allah membebaskan umat-Nya dan membuatnya menjadi umat-Nya. Walter C. Kaiser menjelaskan, kata yang dipakai dalam ayat pertama ini adalah ykina; ('ânokîy), "Aku”, yang merupakan subyek orang pertama tunggal, Aku adalah hw:hy(yehôvah),Yahweh, atau "TUHAN", yang merupakan sebutan dari Allah. Janji pembebasan Israel dari Mesir dikaitkan dengan nama Yahweh di dalam Keluaran 3:14 dan Keluaran 6:6. Sekarang janji itu telah menjadi kenyataan, Dia menyaksikan nama-Nya sekali lagi dengan memberikan hukum-hukum-Nya. Frase ini secara keseluruhan atau sebagian muncul di dalam Keluaran 15:26; 20:5,7,10,12 dan 23:19; tetapi tidak muncul lagi di dalam kitab Bilangan, sementara di dalam kitab Ulangan muncul dua ratus kali.

Pernyataan selanjutnya adalah, "yang membawa engkau keluar dari tanah Mesir, dari tempat perbudakan", menjadi suatu rumusan yang luar biasa di dalam Alkitab dan akan muncul nantinya sebanyak seratus dua puluh lima kali. Dengan pernyataan tersebut menunjukkan bahwa "anugerah" muncul sebelum perintah, hukum, ataupun kewajiban lainnya. ${ }^{15}$ Kata ganti "engkau" disini adalah tunggal, dengan demikian, Allah berfirman kepada seluruh umat Israel secara kolektif sebagai bangsa sekaligus kepada setiap individu. ${ }^{16}$ Dalam ayat kedua ini mengingatkan Israel bahwa TUHAN, yaitu Allah sendirilah yang telah memilih mereka dan membedakan mereka dari bangsa-bangsa lain yang ada di muka bumi. Dengan demikian mereka harus merespon kepada Allah untuk

\footnotetext{
${ }^{13}$ J. Verkuyl, Etika Kristen Bagian Umum (Jakarta: BPK Gunung Mulia, 2005), 97-98.

${ }^{14}$ R. Alan Cole, Exodus: An Introduction and Commentary (Downers Grove: InterVarsity Press, 1973), 151-152.

${ }^{15}$ Kaiser, Old Testaments, 84-85

${ }^{16}$ Robert M. Paterson, Tafsiran Kitab Keluaran (Jakarta: BPK Gunung Mulia, Cet. I, 2006), 262.
} 
memenuhi panggilan dalam hubungan dengan-Nya secara pribadi tanpa ada allah yang lain. Itulah sebabnya hubungan perkawinan diumpamakan sebagai hubungan Allah dengan umat pilihan-Nya. Dalam keduanya, terdapat suatu hubungan pribadi yang terlibat. Kebebasan yang Allah berikan pada Israel adalah kebebasan untuk menyembah-Nya (Kel 4:23). Permintaan tersebut kini dikodifikasikan dalam suatu perintah. Kata-kata ini juga mengingatkan kita bahwa pelayanan Israel dimotivasi oleh ucapan syukur atas apa yang telah Allah lakukan pada mereka.

\section{Perintah Pertama}

Perintah pertama, terdapat di dalam Keluaran 20:3 : "Jangan ada padamu allah lain di hadapan-Ku." Perintah pertama di dalam ayat ketiga ini merupakan dasar semua perintah yang lain. Disini terdapat tuntutan kesetiaan kepada Allah. Bahkan loyalitas demikian harus menjadi pusat seluruh kehidupan serta kelakukan mereka. Mereka harus beribadah kepada TUHAN saja dan dilarang beribadah kepada allah lain.

Menurut Allan Cole dengan perintah ini Allah memerintahkan Israel untuk membangun suatu hubungan yang khusus antara diri-Nya dengan umat-Nya. ${ }^{17}$ Sedangkan menurut Roy B. Zuck, perintah pertama ini membicarakan inti hubungan yang disyaratkan antara perjanjian seorang raja dengan bawahannya. Tuhan telah memilih dan melepaskan umat-Nya dari tuan yang lain (Mesir), karena itu Dia menuntut kesetian mereka kepadaNya tidak bercabang; "jangan ada allah lain dihadapan-KU" (ayat 3), adalah pernyataan yang pasti mengenai tuntutan untuk tunduk dan menyembah hanya kepada TUHAN. Melanggar perintah ini berarti menyangkali seluruh hubungan perjanjian itu, karena hal itu benar-benar merupakan pengkhianatan. ${ }^{18}$

Tetapi apakah artinya perintah tersebut bagi Israel? Apa yang ingin dihindari dari perintah tersebut? Bob Deffinbaugh menjelaskan ada beberapa alasan mengapa Israel diberikan perintah yang pertama ini :

Pertama, dalam sejarah bangsa Israel, mereka seringkali cenderung melakukan penyembahan kepada para dewa orang kafir. Israel seringkali mencari cara untuk menyembah allah lain di samping TUHAN (Yahweh). Rahel mencuri barang-barang berhala ayahnya disaat mereka melarikan diri dari rumah (Kej. 31:9). Israel hidup selama empat ratus tahun di Mesir, suatu bangsa yang memiliki banyak allah dan Israel cenderung terpengaruh untuk mengikutinya (Yos. 24:14; 1 Sam. 8:8). Itulah sebabnya sehingga Israel ditawan karena mereka menolak Allah (Yeh. 20).

Kedua, memiliki allah lain selalu akan menyingkirkan Allah yang benar (bandingkan Yos. 24:15-16, 20; 1 Sam. 8:8). Israel tidak pernah tidak menolak Allah bersamaan dengan melakukan penyembahan kepada allah lain juga. Perjanjian Lama menunjukan secara konsisten bahwa dengan menyembah allah yang lain, maka secara langsung juga akan menyingkirkan Allah. Hubungan Israel dengan Allah bagaikan hubungan suami isteri yaitu

\footnotetext{
${ }^{17}$ Cole, Exodus, 153.

${ }^{18}$ Roy B. Zuck, A Biblical Theology of Old Testament (Teologia Alkitabih Perjanjian Lama), (Malang: Gandum Mas, 2005), 60.
} 
suatu hubungan yang eksklusif yang tidak memberikan ruang kepada yang lainnya. Dengan demikian, di dalam Alkitab, penyimpangan kepada allah lain disebut sebagai persundalan dan perzinahan.

Ketiga, memiliki allah lain adalah suatu bukti kurangnya iman seseorang. Inilah alasan mengapa memiliki allah lain adalah suatu tanda meninggalkan Allah. Perintah ini mengasumsikan bahwa banyak allah akan disembah dan bukan hanya satu. Alasan ini kembali kepada pemahaman teologi kaum pagan (kafir) bahwa suatu allah mempunyai kuasa atas hal tertentu (tapi terbatas). Untuk mengatasi hal tersebut maka seseorang akan menyembah banyak allah. Dengan demikian disaat seseorang mulai meragukan kuasa Allah, allah yang lain akan diperlukan untuk meyakinkan si penyembah bahwa dia disediakan dan dilindungi oleh allahnya itu. Allah dengan demikian akan ditinggalkan disaat allah lain mulai disembah. Perintah ini dengan demikian menekankan kepada kita bahwa disaat kita mulai atau kurang mempercayai kuasa Allah dalam hidup kita, maka kita telah berhenti mempercayai-Nya dan pada waktu yang bersamaan kita telah beralih kepada allah lain.

\section{Perintah Kedua}

Perintah kedua terdapat di dalam Keluaran 20:4-6: Jangan membuat bagimu patung yang menyerupai apa pun yang ada di langit di atas, atau yang ada di bumi di bawah, atau yang ada di dalam air di bawah bumi. Jangan sujud menyembah kepadanya atau beribadah kepadanya, sebab Aku, TUHAN, Allahmu, adalah Allah yang cemburu, yang membalaskan kesalahan bapa kepada anak-anaknya, kepada keturunan yang ketiga dan keempat dari orang-orang yang membenci Aku, tetapi Aku menunjukkan kasih setia kepada beribu-ribu orang, yaitu mereka yang mengasihi Aku dan yang berpegang pada perintah-perintah-Ku."

Robert M. Paterson menjelaskan bahwa perintah kedua ini melarang orang Israel beribadah kepada TUHAN dengan cara yang tidak sesuai dengan sifat-Nya. Karena pada jaman kuno patung dianggap sebagai tempat berdiamnya allah yang diwakilinya. Hal ini berarti bahwa allah itu bersifat statis dan terbatas, bahkan dapat dikendalikan. Patungpatung cenderung menarik manusia sehingga dia berbidah kepada TUHAN seakan-akan sifat-Nya sama dengan sifat allah-allah kafir. Tanpa patung, manusia lebih terbuka terhadap TUHAN dan mengenal sifat-Nya yang sesungguhnya. ${ }^{19}$

Walter C. Kaiser menjelaskan dasar diberikan larangan ini adalah karena "TUHAN, Allahmu, adalah Allah yang cemburu...", istilah "cemburu" dalam bahasa Inggris, "jealous" atau "zealous" God (Ibrani: 'él qanna") tidak dapat diartikan bahwa Allah adalah Allah yang cemburu dalam arti negatif, penuh kecurigaan, tidak suka melihat keberhasilan atau iri. Ketika istilah 'el qannâ dipakai untuk Allah, hal ini menunjukkan; pertama, menunjukkan kualitas dari karakter-Nya yang menuntut pengabdian penuh agar dapat mengenal secara benar siapa yang mereka sembah (Kel. 34:14; Ul. 4:24; 5:9; 6:15), kedua,

\footnotetext{
${ }^{19}$ Paterson, Keluaran, 266.
} 
menunjukkan sifat Allah yang tegas kepada setiap orang yang melawan-Nya (Bil. 25:11; Ul. 29:20; Mzm. 79:5; Yeh. 5:13; 16:38, 42; 35:11 Zef. 1:18), dan ketiga, menunjukkan kuasa yang Dia gunakan untuk menghakimi umat-Nya (2 Raj. 19:31; Yes. 9:7; 37:32; Yoel. 2:18; Zak. 1:14; 8:2). Dengan demikian, kecemburuan adalah suatu ungkapan emosi yang olehnya Allah tergerak atau terdorong untuk bertindak atas apa saja yang menghalangi-Nya. ${ }^{20}$

\section{Perintah Ketiga}

Perintah ketiga terdapat di dalam Keluaran 20:7: "Jangan menyebut nama TUHAN, Allahmu, dengan sembarangan, sebab TUHAN akan memandang bersalah orang yang menyebut nama-Nya dengan sembarangan." Walter C. Kaiser menyatakan bahwa perintah ini melarang orang Israel menggunakan kuasa nama TUHAN untuk tujuan yang tidak sesuai dengan sifat atau maksud-Nya. Nama TUHAN dinyatakan supaya orang dapat memuji Dia dan berseru kepada-Nya dalam doa. Juga menunjuk pada sifat-Nya yang kudus, etis, rahmani, dan yang bertindak secara berkuasa untuk melepaskan umat-Nya dari perbudakan.

Supaya dapat memahami arti dari perintah ketiga ini, ada dua pengertian yang perlu diketahui yaitu :

Pertama, pengertian mengenai konsep nama Allah dan kedua, pengertian dari kata "sia-sia." Keduanya dijelaskan oleh Kaiser: "hal-hal apa sajakah yang melibatkan nama Allah ? nama-Nya melibatkan : pertama, natur-Nya, keberadaan dan pribadi-Nya (Mzm. 20:1; Luk. 24:27; Yoh. 1:12 band. Why. 3:4), kedua, pengajaran-pengajaran-Nya (Mzm. 22:22; Yoh. 17:6, 26) dan, ketiga, pengarahan etika dan moral-Nya (Mik. 4:5).

Kata "sia-sia" atau "maksud yang kosong" dalam menyebut nama Allah adalah berarti : pertama, mengkonfirmasikan sesuatu yang bohong atau tidak benar, kedua, menahan sesuatu dalam pembicaraan atau doa, ketiga, mengekspresikan keheranan yang halus, dan keempat, menggunakan nama tersebut untuk suatu maksud yang tidak jelas tujuannya apakah dalam doa maupun konteks keagamaan.

Di dalam Amsal 18:10 disebutkan bahwa "nama TUHAN adalah menara yang kuat, kesanalah orang benar berlari dan ia menjadi selamat." 21

J. Coert Rylaarsdam menjelaskan bahwa perintah ini tidak mengatakan bahwa bersumpah itu adalah dosa dan salah. Banyak sekali bagian di dalam kitab Ulangan, seperti Ulangan 6:13 menguatkan bahwa kita harus bersumpah demi nama-Nya. Tetapi sumpah yang demikian haru dilakukan sebagaimana yang dikatakan di dalam Yeremia 4:2 "Dan jika engkau bersumpah dalam kesetiaan, dalam keadilan dan dalam kebenaran: Demi TUHAN yang hidup!, maka bangsa-bangsa akan saling memberkati di dalam Dia dan akan bermegah di dalam Dia."

\footnotetext{
${ }^{20}$ Kaiser, Old Testament, 86.

${ }^{21}$ Kaiser, Old Testament, 88.
} 


\section{Perintah Keempat}

Perintah keempat terdapat di dalam Keluaran 20:8-11: "Ingatlah dan kuduskanlah hari Sabat: enam hari lamanya engkau akan bekerja dan melakukan segala pekerjaanmu, tetapi hari ketujuh adalah hari Sabat TUHAN, Allahmu; maka jangan melakukan sesuatu pekerjaan, engkau atau anakmu laki-laki, atau anakmu perempuan, atau hambamu lakilaki, atau hambamu perempuan, atau hewanmu atau orang asing yang di tempat kediamanmu.Sebab enam hari lamanya TUHAN menjadikan langit dan bumi, laut dan segala isinya, dan Ia berhenti pada hari ketujuh; itulah sebabnya TUHAN memberkati hari Sabat dan menguduskannya."

Bob Deffinbaugh menyatakan bahwa ada beberapa alasan mengapa Sabat menjadi pokok pembahasan utama, karena Sabat adalah salah satu dari perintah yang penting dari Sepuluh Perintah. Sabat adalah bagian dari perintah yang berkaitan dengan hubungan kita dengan Allah dan Sabat adalah juga merupakan perintah yang dipilih sebagai "tanda" dari keseluruhan perjanjian Musa (Kel. 31:13). Pelanggaran terhadap perintah ini akan berakibat kepada hukuman mati (Kel. 31:14). Memahami arti Sabat akan memberikan nilai yang sangat berharga di dalam mempelajari, menafsirkan dan mengaplikasikan Kitab Suci.

Perintah mengenai Sabat dimulai bersamaan dengan kelahiran bangsa Israel sebagaimana digambarkan di dalam kitab Keluaran. Terdapat dua bagian penting yang harus dipertimbangkan, karena bangsa Israel tidak akan diberikan suatu perintah ini tanpa ada yang mendasarinya. Hal pertama yang harus dipertimbangkan adalah "perhentian Sabat Tuhan di dalam Kejadian 2:1-3 dan "Sabat perhentian Israel" yang berhubungan dengan pengumpulan mana di dalam Keluaran 16:22-30. Di dalam Kejadian 2:1-3 dikatakan: "Demikianlah diselesaikan langit dan bumi dan segala isinya. Ketika Allah pada hari ketujuh telah menyelesaikan pekerjaan yang dibuat-Nya itu, berhentilah Ia pada hari ketujuh dari segala pekerjaan yang telah dibuat-Nya itu." (Kej 2:1-3).

Prinsip yang diberikan dari teks diatas adalah membangun suatu panduan yang menjadi dasar perintah Sabat. Panduan tersebut dibangun oleh Allah sendiri, yang berhubungan dengan masa tujuh hari penciptaan. Pekerjaan penciptaan telah diselesaikan dalam enam hari, pada hari ketujuh Allah beristirahat karena Dia telah menyelesaikan pekerjaan penciptaan-Nya. Kemudian Allah memberkati dan menguduskan hari tersebut karena pada hari tersebut Dia beristirahat. Teks tersebut memiliki tiga gagasan yang berbeda yang saling berhubungan yaitu: Pertama, Allah menyelesaikan pekerjaan-Nya menciptakan dunia. Kedua, Allah beristirahat pada hari ketujuh karena pekerjaan penciptaan-Nya telah diselesaikan. Ketiga, Allah memberkati dan menguduskan hari ketujuh karena Dia beristirahat pada hari tersebut.

\section{Perintah Kelima}

Perintah kelima terdapat di dalam Kel 20:12 : "Hormatilah ayahmu dan ibumu, supaya lanjut umurmu di tanah yang diberikan TUHAN, Allahmu, kepadamu." Robert Paterson mengatakan, kalau keempat perintah pertama mengenai kewajiban orang Israel terhadap Allah, maka perintah kelima adalah kewajiban orang Israel terhadap sesamanya 
(sesama manusia). Yang pertama dari perintah itu adalah perintah untuk menghormati ayah dan ibu sebagai sesama yang terdekat. Lebih lanjut Paterson mengatakan bahwa tujuan pokok dari perintah ini adalah bukan mengajar anak-anak kecil ataupun anak-anak muda (para pemuda) tentang sikap mereka terhadap orang tua mereka, tetapi lebih kepada mengajarkan anak-anak dewasa akan sikap mereka terhadap orang tua mereka yang telah lanjut usia dan yang kekuatannya sudah berkurang. Seorang Israel tidak bisa menilai rendah orang tua atau memperlakukan mereka secara keras, dan tidak bisa menolak memberikan makanan dan apapun yang dibutuhkan mereka atau memaksa orang tua meninggalkan rumah kediaman anaknya. Arti kata "ayah dan ibumu" di ayat ini bisa diperluas sehingga termasuk semua keluarga yang sudah tua. ${ }^{22}$

Bob Deffinbaugh mengatakan bahwa pokok tentang menghormati orang tua adalah salah satu hal yang penting. Salah satu alasannya adalah bahwa baik Perjanjian Lama maupun Perjanjian Baru memerintahkan kita untuk menghormati orang tua kita. Perintah ini harus dianggap sebagai sesuatu yang serius bukan karena hanya Perjanjian Lama yang menyatakannya tetapi karena kewajiban untuk menghormati orang tua adalah salah satu yang diulangi dan ditekankan kembali di dalam Perjanjian Baru: "Hai anak-anak, taatilah orang tuamu di dalam Tuhan, karena haruslah demikian. Hormatilah ayahmu dan ibumu -ini adalah suatu perintah yang penting, seperti yang nyata dari janji ini: supaya kamu berbahagia dan panjang umurmu di bumi." (Ef. 6:1-3).

Dengan demikian, menghormati orang tua kita adalah suatu perintah yang tidak boleh kita abaikan. Alasan yang mendasari untuk mempelajari dengan seksama perintah kelima, yaitu menghormati orang tua, adalah karena perintah ini merupakan salah satu panggilan tertinggi dan tugas yang terbesar di dalam kehidupan manusia. Ada dua panggilan terbesar dalam kehidupan manusia, yang pertama adalah menghormati dan merawat orang tua dan yang kedua adalah panggilan untuk mengandung dan membesarkan anak, membawa mereka dari keadaan yang tak berdaya sejak dalam kandungan kepada keadaan menjadi mandiri dan dewasa.

\section{Perintah Keenam}

Perintah keenam terdapat di dalam Keluaran 20:13: "Jangan membunuh." Dalam bahasa Ibrani terdapat tujuh kata yang berhubungan dengan "membunuh". Walter C. Kaiser menjelaskan; kata yang diapakai disini adalah רָצָ (ratsakh) yang berhubungan dengan "membunuh musuh". Kata רָָָ ini muncul empat puluh tujuh kali di dalam Perjanjian Lama dan merujuk kepada: membunuh untuk pembalasan (Bil. 35:27, 30), pembunuhan biasa (2 Raj. 6:32) dan bahkan pembunuhan manusia oleh singa (Ams. 22:13). Tetapi tidak termasuk pembunuhan binatang liar untuk makanan (Kej. 9:3), membunuh untuk mempertahankan rumah dari pencuri (Kel. 22:2), pembunuhan yang tidak disengaja (Bil. 19:5), pelaksanaan hukuman mati oleh negara (Kej. 9:6) atau pembunuhan di dalam peperangan. ${ }^{23}$

\footnotetext{
${ }^{22}$ Paterson, Keluaran, 269.

${ }^{23}$ Kaiser, Old Testament, 90
} 
Menurut Kaiser, hukum pentatuk menunjukkan bagaimana perintah keenam diaplikasikan. Seseorang atau binatang yang menyebabkan kematian orang lain haruslah dihukum mati (Kel. 21:12, 28-32). Di bagian hukum lainnya, ketika dua orang laki-laki dan menyebabkab seorang perempuan keguguran, maka janin tersebut dianggap sebagai mahluk hidup sehingga tindakan tersebut akan dianggap sebagai penghilangan nyawa manusia (Kel. 21:22-25).

Bob Deffinbaugh mengatakan bahwa bagi Allah memberikan hidup kepada manusia adalah merupakan bagian yang terutama dari segala karya-Nya (Kej. 2:7). Allah terlibat secara nyata di dalam proses pemberian hidup kepada manusia. Dia memberikan nafas kehidupan kepada manusia. Hal ini berbeda dari cara Dia memberikan hidup kepada mahluk yang lainnya; Allah menciptakan manusia menurut gambar dan rupa-Nya (Kej. 1:26). Karena manusia adalah merupakan refleksi dari gambar dan rupa Allah (diciptakan menurut gambar dan rupa-Nya), maka manusia berbeda, dan juga manusia menjadi hidup melalui cara yang berbeda dengan mahluk yang lainnya. Oleh karenanya, manusia tidak boleh atau merasa berhak untuk mengambil kehidupan (termasuk dirinya sendiri) sebagaimana dikatakan oleh Ayub bahwa TUHAN yang memberi, TUHAN yang mengambil, terpujilah nama TUHAN!" (Ayb. 1:21).

Hidup itu "kudus" memiliki arti: Pertama, karena hidup itu berasal dari Allah. Tak ada sumber hidup yang lain kecuali Dia. Allah yang hidup adalah Allah yang menghidupkan. Kedua, hidup itu kudus sebab kehidupan adalah satu-satunya yang dikehendaki Allah dan bukan kematian atau kebinasaan.

Dasar teologis inilah yang dapat menjelaskan secara tepat perlunya hukuman yang keras terhadap pembunuhan, sebab itu konsekuensi dari pembunuhan ini adalah hukuman mati, dan menerangkan hukuman yang berlaku universal serta pembalasan atas perbuatan tersebut yang juga berlaku di luar bangsa Israel. Mengapa hukuman itu diperlukan?

\section{Perintah Ketujuh}

Perintah ketujuh terdapat di dalam Keluaran 20:14: "Jangan berzinah." Walter C.Kaiser menjelaskan, kata yang dipakai disini adalah nâph atau "berzinah", yang berlaku baik untuk laki-laki maupun perempuan. Karena hukuman untuk perbuatan zinah (antara laki-laki dan perempuan yang telah menikah) adalah hukuman mati (Ul. 22:22) sementara hukuman perbuatan seks di luar nikah yang mengakibatkan hilangnya keperawanan seorang perempuan adalah pengenaan denda mengawini si perempuan ataupun dalam bentuk uang (Kel. 22:16-17; Ul. 22:23-29), dengan demikian maka perbuatan zinah dibedakan dari tindakan melakukan hubungan seks di dalam Perjanjian Lama. ${ }^{24}$ Lebih lanjut Kaiser menyatakan bahwa; persoalan mengenai perzinahan tidak melulu menunjuk kepada menodai milik seseorang; tetapi hal ini juga menyangkut persoalan moral. Yusuf mengetahui bahwa dengan menerima tawaran isteri Potifar adalah

\footnotetext{
${ }^{24}$ Kaiser, The Expositor's, 425.
} 
merupakan dosa terhadap Allah dan juga terhadap Potifar (Kej. 39:9). Di bagian lain, Abimelek menyebut perzinahan sebagai "dosa besar" (Kej. 20:9).

Kejadian 2:23-24 adalah merupakan dasar yang kuat untuk monogami. Orang pertama yang menyimpang dengan melakukan poligami adalah Lamekh (Kej. 4:19) yang menikahi dua orang wanita. Kasus seperti ini tidak banyak terjadi di masa Perjanjian Lama, sehingga jelaslah bahwa poligami adalah suatu bukti dari kejatuhan manusia ke dalam dosa. Setelah Lamekh, Abrahampun demikian (Hagar, Kej. 16:1-2), Nahor (Reuma, Kej. 22:20-24), anak Esau, Elifas (Kej. 36:11-12), Yakub, menikahi dua orang wanita bersaudara (Kej. 29:15-30; 30:1-9), Esau memiliki tiga orang isteri (Kej. 26:34; 28:9; 36:15 ), dan Gideon juga mempunyai banyak isteri dan paling tidak satu orang gundik (Hak. 8:30-31). Namun demikian, bentuk pernikahan yang paling umum di Israel adalah monogami. Di dalam keseluruhan kitab Samuel dan Raja-Raja satu-satunya kasus poligami adalah ayah Samuel dengan dua isterinya Hana dan Peninah (1 Sam. 1:2). Raja-raja Israel dan Yehuda mengikuti yang dilakukan oleh pendahulu mereka yaitu Saul, Daud dan Salomo. $^{25}$

Mengapa melakukan perzinahan hukumannya lebih berat (hukuman mati) dibandingkan dengan dosa seksual yang lainnya? Michael Eaton menjelaskan; "Hal ini jelas, karena hukum bangsa Israel sangat melindungi keutuhan keluarga. Perzinahan dianggap sebagai tindakan yang sangat dan bahkan paling buruk dibanding dengan tindakan pelanggaran seksual lainnya karena perzinahan memecah keutuhan suatu keluarga. Dosa perzinahan ditempatkan setingkat dengan pembunuhan; karena perzinahan akan berakibat memecah keutuhan keluarga dan dengan demikian juga keutuhan bangsa. Dengan adanya perzinahan maka kehidupan keluarga akan guncang, yang berakibat kestabilan bangsa juga akan guncang. Ketabilan bangsa Israel sangat penting bagi Allah, oleh sebab itu pelanggaran terhadap perintah ini akan dikenakan hukuman mati."26

\section{Perintah Kedelapan}

Perintah kedelapan terdapat di dalam Keluaran 20:15: "Jangan mencuri." Menurut Walter C. Kaiser, bahasa Ibrani yang dipakai disini adalah genob atau "mencuri". Yang dimaksud "mencuri" disini adalah mengambil dari seseorang (milik seseorang) ataupun dari suatu obyek. ${ }^{27}$ Bob Deffinbaugh menjelaskan perintah ini menyatakan bahwa Allah memiliki segala sesuatunya di bumi maupun di sorga (Mzm. 24:1; 115:16), dan Dia bukan saja dapat memberikan tetapi juga Dia dapat menyingkirkannya. Dengan demikian, tidak boleh seorangpun yang berhak untuk mengambil secara paksa sesuatu yang bukan miliknya (haknya).

Perintah ini bertujuan untuk melindungi hak milik setiap orang. Supaya tidak terjadi kerugian akibat ulah seseorang, hak milik semua orang dijamin dengan hukum ganti

\footnotetext{
${ }^{25}$ Kaiser, Old Testament, 92-23.

${ }^{26}$ Michael Eaton, Preaching Through The Bible, Exodus 1-20, (Tonbridge: Sovereign World, 2002),

${ }^{27}$ Kaiser, The Expositor's, 425.
} 119. 
rugi (Kel. 22:1-17). Dalam pandangan bangsa Israel, segala kepunyaan seseorang menyatu dengan orang tersebut (1 Raj. 21:2-3), dengan demikian, semua miliknya merupakan representasi dari dirinya sendiri (Yos. 7:24-25). Jadi mencuri milik seseorang berarti mencederai keutuhan pribadi orang itu (2 Sam. 11:1-27; 1 Raj. 21:1-16). Karena itu bangsa Israel dilarang keras untuk mencuri milik kepunyaan seseorang.

Perintah ini juga membicarakan hal penting mengenai hubungan penguasa dengan bawahannya: yaitu mengenai harta benda dan pengelolaan, serta pembagian yang pantas. Hal ini akan mempunyai makna yang jelas hanya jika orang mengakui bahwa semua bangsa (dan khususnya Israel) adalah hamba yang mengabdi kepada Allah, Sang Pencipta dan Penebus yang telah memberikan semua harta itu, dan mengharapaan pengelolaan (penatalayanan) yang masuk akan semua itu. Raja (Allah) tersebut bukan hanya membagibagikan lingkup wewenang dan tanggung jawab, melainkan juga telah memberi masingmasing bawahan itu sarana untuk melaksanakan maksud-Nya bagi mereka masing-masing di bumi.

Karena itu, dengan mencuri maka orang paling tidak telah melakukan tiga macam dosa kepada Allah, Pertama, merampas dari orang lain sesuatu yang telah diberikan kepadanya dan kebutuhan-kebutuhan untuk melaksanakan penatalayanan atau pengelolaan atas semua itu, kedua, tidak dapat melakukan sendiri tugasnya berdasarkan apa yang telah diberikan Allah kepadanya, dan ketiga, merusak maksud-maksud yang bijaksana dari Allah, yang telah memberi masing-masing orang sesuai dengan peran dan kemampuannya. Segala sesuatu, baik materi maupun bukan, adalah milik Allah dan harus dibagikan menurut kehendak-Nya.

\section{Perintah Kesembilan}

Perintah kesembilan terdapat di dalam Keluaran 20:16: "Jangan mengucapkan saksi dusta tentang sesamamu." Atau tepatnya berbunyi:"Janganlah naik saksi sebagai saksi dusta terhadap sesama manusia." C. Barth mengatakan bahwa perintah ini memperlihatkan dengan lebih jelas kepada kita latar belakang diberikannya perintah ini yaitu suatu perintah yang ditujukan khusus kepada orang-orang Israel yang dipanggil untuk menjadi saksi di muka pengadilan. Perintah ini selain merupakan larangan bersifat umum yang melarang untuk berbohong juga berkaitan dengan kesaksian palsu. Berkaitan dengan kesaksian palsu (dusta), perintah ini menjadi sangat penting karena hidup matinya seorang terdakwa akan bergantung kepada kesaksian yang diberikan oleh perkataan saksi, oleh sebab itu perintah Allah ini melarang untuk bersaksi palsu (dusta) dengan sewenang-wenang kepada sesama manusia $^{28}$.

Roy B. Zuck mengatakan bahwa walaupun kata "sesama" (Ibrani: re rêya") sering menunjuk kepada orang yang tidak dikenal, atau bahkan juga orang asing (Kel. 11:2), tetapi dalam rangka sebuah dokumen perjanjian kata itu jelas memaksudkan sesama orang Israel. Ungkapan ini merupakan bahasa teknis yang sah. Dalam hak praktisnya perintah ini

\footnotetext{
${ }^{28}$ Barth, Theologia, 328.
} 
mengajarkan bahwa dalam pengadilan orang tidak boleh memberikan kesaksian palsu tentang pihak tertuduh (Kel. 23:1,7; Ul. 19:15-19). Kata yang dipakai untuk "kesaksian" adalah kata yang dipakai untuk ketentuan- ketentuan dari sebuah dokumen perjanjian di Israel dan masyarakat Timur Kuno. ${ }^{29}$

Dalam memberikan kesaksian tentang sesuatu perkara, menurut Hendrik Njiolah, bangsa Israel harus mengatakan kebenaran. Mereka tidak boleh membelokkan hukum dengan menyebarkan kabar bohong (Kel. 23:1-2). Supaya tetap berpegang pada kebenaran, mereka sama sekali tidak boleh memihak baik kepada orang miskin (Kel. 23:3) maupun kepada orang kaya (Kel. 23:6). Dan untuk menjaga kekudusan nama TUHAN, mereka dilarang keras untuk berbohong, berdusta dan bersumpah palsu demi nama TUHAN (Im. 19:11-12). Singkatnya, bangsa Israel harus menjauhkan diri dari segala dusta, dan tidak boleh merugikan orang benar yang tidak bersalah (Kel. 23:7). Jika para saksi ternyata berbohong dan berdusta, mereka harus dihukum mati, karena mereka telah menodai kekudusan umat TUHAN (Ul. 19:16-21). ${ }^{30}$

\section{Perintah Kesepuluh}

Perintah kesepuluh terdapat di dalam Keluaran 20:17: "Jangan mengingini rumah sesamamu; jangan mengingini isterinya, atau hambanya laki-laki, atau hambanya perempuan, atau lembunya atau keledainya, atau apa pun yang dipunyai sesamamu." C. Barth menjelaskan bahwa, kata yang dipakai disini adalah חָ (khamad) yang berarti "mengingini dengan sangat", "merindukan sekali", atau "iri hati". Kata ini paralel dengan kata 'âेah yang terdapat di dalam Ulangan 5:21 yang berarti "mengingini sesuatu." Perintah ini menjadi penting karena pemakaian kata kerja kata $\mathrm{hW}<\mathrm{a}$ tidak hanya terbatas pada mengingini (hasrat hati) saja tetapi melainkan juga termasuk suatu gerakan tangan atau tindakan yang nyata. "Mengingini" selalu disusul dengan "mengambil" (Yos. 7:21; Mi 2:2), malah kadang-kadang berarti "mengambil” (Mzm. 68:17; Kel. 34:24). Baik rumah, isteri, tanah, budak laki-laki dan perempuan dan ternak adalah kepunyaan orang Israel merdeka, "milik" yang dilindungi oleh hukum Allah (Kel. 22:1-17) ${ }^{31}$

Lebih lanjut Hendrik P. Njiolah mengatakan bahwa perintah ini adalah merupakan perintah terakhir dalam Sepuluh Perintah yang melarang orang untuk mengingini milik orang lain (iri hati). Secara teoritis keinginan biasanya hanya terdapat dalam angan-angan dan dalam hati, serta tidak pernah nampak dalam tindakan lahiriah. Tetapi, pada saat iri hati nampak dalam bentuk lahiriahnya maka itu bukan lagi suatu keinginan. Namun demikian walaupun keinginan hati karena menginginkan sesuatu tidak pernah dinyatakan melalui tindakan nyata, hal itu tetap pelanggaran serius, sebab Tuhan yang mengetahui hati akan terganggu olehnya.

\footnotetext{
${ }^{29}$ Zuck, A Biblical Theology, 81.

${ }^{30}$ P. Hendrik Njiolah, Pr, Sepuluh Perintah Allah, (Yogyakarta: Yayasan Pustaka Nusatama, 2003), 40-41.

${ }^{31}$ Barth, Theologia, 328-329.
} 
Keinginan hati, mengungkapkan perasaan tidak puas berkaitan dengan harta milik orang lain dan terhadap nasib hidupnya secara umum. Keinginan hati melanggar (meskipun hanya dalam roh) kesucian milik pribadi serta hubungan-hubungan, dan cenderung mengganggu batasan hukum yang seimbang dan wajar yang ditetapkan oleh si pembuat hukum. Sebenarnya keinginan hati adalah sikap meragukan kebijaksanaan dan kebajikan Allah dengan mempertanyakan pemberian-Nya berupa berkat-berkat dalam hidup ini sesuai dengan rencana-Nya yang Mahatahu.

Dari pembahasan diatas, fungsi formal teologis Sepuluh Perintah Allah menjadi jelas ketika dilihat menurut konteks penebusan dalam kitab Keluaran dan melalui maksud Allah memilih Israel menjadi bangsa pilihan-Nya, yang dibawa ke dalam hubungan perjanjian dengan Dia untuk melayani sebagai kerajaan imam (imamat rajani). Janji Allah kepada Abraham menguatkan bahwa keturunannya itu akan diberkati dan akan tidak terhitung jumlahnya. Keturunannya itu akan mewarisi negeri yang akan menjadi basis geografis, dimana bangsa pilihan itu menjadi alat Allah untuk memberkati dunia. Peristiwa keluaran telah membebaskan bangsa Israel keluar dari tempat perbudakan untuk mengabdi kepada tuan lain, sehingga mereka dapat melaksanankan tanggung jawab sepenuhnya hanya kepada tuannya itu, yaitu TUHAN.

Tuhan Yesus mengatakan: "Janganlah kamu menyangka, bahwa Aku datang untuk meniadakan hukum Taurat atau kitab para nabi. Aku datang bukan untuk meniadakannya, melainkan untuk menggenapinya. Karena Aku berkata kepadamu: Sesungguhnya selama belum lenyap langit dan bumi ini, satu iota atau satu titik pun tidak akan ditiadakan dari hukum Taurat, sebelum semuanya terjadi." Mat. 5:17-18). Kata "menggenapi" menurut Fritz Rienecker berasal dari bahasa Yunani; $\pi \lambda \eta \rho$ ó $\omega$, adalah suatu yang pasti. Arti kata $\pi \lambda \eta \rho$ ó ini adalah "menggenapi," atau "memenuhi dengan pasti." 32

Melalui pernyataan tersebut Tuhan Yesus berbicara mengenai bagaimana pengajaran-Nya berhubungan dengan tuntutan Allah di dalam hukum Perjanjian Lama. Hal ini menunjukkan bahwa ada kesinambungan yang kuat antara pengajaran Tuhan Yesus dengan dan hukum Taurat dan dengan jelas dinyatakan bahwa penggenapan hukum Taurat oleh Yesus terdiri atas tindakan-Nya menetapkan dan menjunjung tinggi hukum Taurat, memberikan kepada hukum itu arti yang sebenarnya dalam rangka menanggapi usahausaha orang Yahudi untuk mengelakkan artinya yang lengkap. Dengan pernyataan ini juga, Tuhan Yesus menekankan bahwa hukum Taurat itu terus berlaku dan terus bermanfaat jikalau dilihat dari

\section{KESIMPULAN}

Dari pembahasan sebelumnya diketahui bahwa sepuluh perintah Allah adalah merupakan kabar baik yang disampaikan bagi Israel dan juga bagi orang percaya. Sepuluh Perintah Allah merupakan kabar baik yang Allah telah berikan kepada kita untuk dilaksanakan. Yang dimaksudkan dengan kabar baik adalah bahwa Sepuluh Perintah, yang

\footnotetext{
${ }^{32}$ Fritz Rienecker, A Linguistic Key To The Greek New Testament (Grand Rapids: Zondervan Publishing House, 1980), 13.
} 
sebagian besar di dalam setiap perintahnya berupa larangan atau hal yang negatif namun dibalik itu semua Allah mempunyai maksud yang baik, yang hanya ditujukkan bagi kita.

Robert J. Wieland mengatakan bahwa, misalkan, ketika perintah kedelapan yang mengatakan,"Jangan mencuri!" apa yang sebenarnya dikatakan adalah bahwa Tuhan akan menyelamatkan kita dari tindakan mencuri bahkan mencuri seutas tali sepatupun! kita tidak akan mendapat masalah jika kita tidak mencuri, bahkan saat kita sendirian di ruangan penuh dengan sejumlah uang yang besar di meja, Tuhan akan menyelamatkan kita dari tindakan melakukan pencurian.

Dan saat perintah ketujuh mengatakan,"Jangan berzinah!” apa yang sebenarnya dikatakan adalah bahwa Tuhan akan menyelamatkan kita dari kejatuhan kedalam lubang penipuan seksual, betapapun nikmatnya godaan seksual itu. Amsal mengatakan bahwa; "Mulut perempuan jalang adalah lobang yang dalam; orang yang dimurkai TUHAN akan terperosok ke dalamnya." (Ams. 22:14). Kesengsaraan yang akan kita hindari sangatlah besar dengan mematuhi perintah tersebut. Sesungguhnya, Sepuluh Perintah Allah adalah merupakan suatu kabar baik yang tidak pernah diperhatikan orang, yaitu: sepuluh kabar baik yang menyenangkan. ${ }^{33}$

Di dalam Roma 8:2-4, Paulus menjelaskan: "Roh, yang memberi hidup telah memerdekakan kamu dalam Kristus dari hukum dosa dan hukum maut. Sebab apa yang tidak mungkin dilakukan hukum Taurat karena tak berdaya oleh daging, telah dilakukan oleh Allah. Dengan jalan mengutus Anak-Nya sendiri dalam daging, yang serupa dengan daging yang dikuasai dosa karena dosa, Ia telah menjatuhkan hukuman atas dosa di dalam daging, supaya tuntutan hukum Taurat digenapi di dalam kita, yang tidak hidup menurut daging, tetapi menurut Roh." Di dalam surat Roma tersebut Paulus menjelaskan bahwa: Pertama, Sepuluh Perintah tidak bisa menyelamatkan siapapun (tidak ada satu hukumpun yang dapat menyelamatkan). Kedua, Allah memberikan solusi atas masalah dosa kita dengan mengirimkan Anak-Nya. Ketiga, Yesus telah menang dan mengalahkan dosa di dalam tubuh kita yang telah jatuh dan berdosa. Keempat, semua pencapaian luar biasa yang Yesus telah menangkan adalah dengan tujuan "supaya kita hidup tidak menurut daging tetapi menurut Roh." Inilah kabar baik yang sesungguhnya yang telah Allah rencanakan bagi kita, yaitu mengutus Yesus Kristus anak-Nya yang tunggal untuk melepaskan manusia dari belenggu dosa.

\section{REFERENSI}

Roger Nicole, "The Old Testament in the New Testament," dalam The Expositor's Bible Commentary, ed. Frank E. Gaebelein (Grand Rapids: Zondervan, 1979)

Wellinton Pandensolang, Argumentasi Teologis Tentang Parousia Berdasarkan 1 Tesalonika 4:13-15 dan Wahyu 19:6-20:15 (Tesis Th.M., Sekolah Tinggi Teologia Injili Indonesia, 2003)

\footnotetext{
${ }^{33}$ Robert J. Wieland, Kabar Baik dari 10 Hukum Allah (Jakarta: CMC, 2006), 1-2.
} 
Umberto Cassuto, A Commentary on the Book of Exodus, translated by Israel Abrahams (Magnes Press: Reprinted English, ed. Jerusalem)

Wolf, Herbert, Pengenalan Pentateukh, (Malang: Gandum Mas, cet. kedua, 2004)

Jack S. Deere "Deuteronomy," dalam The Bible Knowledge Commentary: Old Testament, pen. John F. Walvoord and Roy B. Zuck (Wheaton: Scripture Press Publications, Victor Books, 1985)

Philip C. Johnson, "Exodus,"dalam The Wycliffe Bible Commentary, pen., Charles F. Pfeiffer and Everett F. Harrison (Chicago: Moody Press, 1962)

Artikel: www.biblescripture.net/Commandments.htm.l

R. Alan Cole, Exodus: An Introduction and Commentary (Downers Grove: InterVarsity Press, 1973)

Robert M. Paterson, Tafsiran Kitab Keluaran (Jakarta: BPK Gunung Mulia, Cet. I, 2006)

Roy B. Zuck, A Biblical Theology of Old Testament (Teologia Alkitabih Perjanjian Lama), (Malang: Gandum Mas, 2005)

Johan J. Stamm and Maurice E. Andrew, The Ten Commandement in Recent Research (Napperville: Allenson, 1962)

William Foxwell Albright, From Stone Age to Christianity, 2d ed (New York: Doubleday, 1957)

Michael Eaton, Preaching Through The Bible, Exodus 1-20, (Tonbridge: Sovereign World, 2002)

Bob Deffinbaugh, "The Sin of Stealing", Artikel : www.bible.org, 1-3.

Hendrik Njiolah, Pr, Sepuluh Perintah Allah, (Yogyakarta: Yayasan Pustaka Nusatama, 2003)

Darmaputera, Eka. Sepuluh Perintah Allah Musiumkan Saja, (Jakarta: PT Gloria Usaha Mulia, 2005)

Kaiser, Walter C. Jr. The Expositor's Bible Commentary Vol 2: Exodus, (Grand Rapids: Zondervan Corporation, 1990) Toward Old Testament Ethics, (Grand Rapids:Zondervan Publishing House, 1991)

Verkuyl, J. Etika Kristen Bagian Umum, (Jakarta: BPK Gunung Mulia, cetakan 20, 2005)

Sprinkle, Joe M. Law and Narrartive in Exodus 19-24, (Journal of the Evangelical Theological Society, Jun 2004)

Rylaarsdam, J. Coert and J. Edgar Park, "The Book of Exodus," The Interpreter's Bible (New York: Abingdon, 1952)

Zuck,Roy B. A Biblical Theology of Old Testament (Teologia Alkitabih Perjanjian Lama), (Malang: Gandum Mas, cetakan pertama, 2005)

C. Barth. Theologia Perjanjian Lama I, (Jakarta BPK Gunung Mulia, cetakan 11, 2006)

Wieland, Robert J. Kabar Baik dari 10 Hukum Allah, (Jakarta: CMC, cetakan I, 2006)

Fritz Rienecker, A Linguistic Key To The Greek New Testament (Grand Rapids: Zondervan Publishing House, 1980) 